\title{
COMPARISON OF THE SILVER AND IODINE VOLTAME- TERS AND THE DETERMINATION OF THE VALUE OF THE FARADAY
}

By G. W. Vinal and S. J. Bates

\section{CONTENTS}

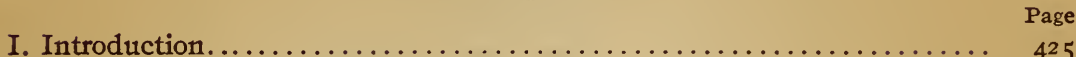

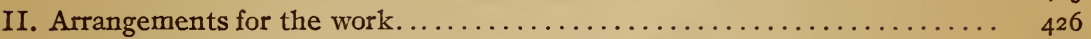

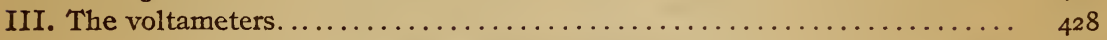

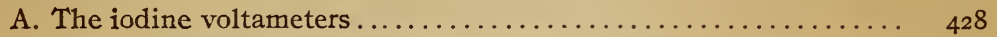

I. Apparatus and manipulation.................. 428

2. Chemicals and solutions..................... 429

3. Methods of standardization and analysis.............. $43 \mathrm{I}$

4. Strength of the standard arsenious acid solution......... 435

B. The silver voltameters......................... 437

r. Forms used.............................. 437

2. Materiais, etc........................... 437

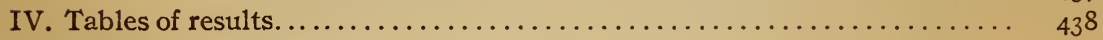

V. Discussion of results.................................. 443

A. The silver-iodine ratio $\ldots \ldots \ldots \ldots \ldots \ldots \ldots \ldots \ldots \ldots \ldots \ldots \ldots \ldots \ldots \ldots \ldots \ldots, 443$

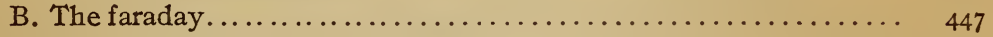

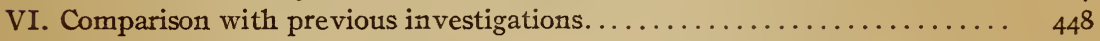

A. The silver voltameter............................. 448

B. The iodine voltameter......................... 448

VII. Summary ....................................... 449

\section{INTRODUCTION}

Of the many electrochemical reactions which may theoretically be employed to determine the faraday, i. e., the quantity of electricity associated with a chemical equivalent in any electrochemical change, that of the deposition of silver from a solution of silver nitrate is the only one that has been extensively investigated. The values which have been accepted for the faraday from time to time have almost entirely been based upon results with the silver voltameter. This naturally resulted from the fact that the international ampere is defined in terms of the silver deposited under more or less rigorously fixed conditions, and hence this instrument has been the subject of many thorough investigations both by the national standardizing laboratories and by private individuals. 
As a result of tnese investigations it has been possible for the past few years so to define the conditions to be used in connections with the silver voltameter that a reproducibility of $\mathrm{I}$ or 2 parts in 100000 may be obtained. Until recently no other voltameter had attained anything approaching such a degree of precision

A little over a year ago, however, Washburn and Bates ${ }^{1}$ published the results of a study of an iodine voltameter which they had devised and which was found to have a reproducibilitv of the same order as that of the silver voltameter. The apparently complete reversibility and purity of the electrochemical reaction in the iodine voltameter, coupled with the fact that no solid deposit is obtained, made it a particularly valuable reaction to employ for determining the faraday and warranted very exact electrical measurements. Since the Bureau of Standards had as a result of recent work on the silver voltameter exceptional facilities for such measurements, arrangements were made for the comparison during the summer of 1913 of the silver and the iodine voltameters at the Bureau of Standards.

\section{ARRANGEMENTS FOR THE WORK}

So far as the methods of making the silver deposits and washing, drying, and weighing them are concerned, no essential changes from those previously employed ${ }^{2}$ at the Bureau of Standards were made. But the methods of measuring the current had to be somewhat modified owing to the high resistance of the iodine voltameters and the smaller current to be employed. An electromotive force of 240 volts was used to pass a current of one-fourth of an ampere through the circuit containing the voltameters and the ballast resistance of about 400 ohms. This necessitated particularly high insulation owing to the damp weather which is prevalent in Washington in summer. Fortunately this was obtainable by mounting the galvanometers and all apparatus on paraffin and using paraffin insulators to support all wires pertaining to the circuit. The circuit is shown diagrammatically in Fig. I The current was measured by means of a Wolff potentiometer (P), and also by directly balancing (B) the electromotive force of a Weston standard cell (No. 109) maintained at $28^{\circ}$ in oil against the fall in potential across two 2 -ohm resistance standards $(R)$, through a second 
galvanometer, similarly to the method previously described. ${ }^{3}$ To eliminate the errors of the potentiometer, however, the dials were set to the voltage of the cell as nearly as possible and balanced with the standard cell on the same terminals to which the emf of the standard resistance was applied. To facilitate this a double pole, double-throw switch $\left(\mathrm{S}_{2}\right)$ with all joints soldered and embedded in paraffin was used. $Q$ is a series resistance for quick adjustment of the current, $\mathrm{A}$ is an ammeter for convenience, $\mathrm{C}$ the compensating resistance usually about $590 \mathrm{ohms}, \mathrm{K}$ is a Kelvin rheostat for fine regulation, $S_{1}$ is the main switch to throw the current on or off through the voltameters $V$. As a test of the circuit a comparison of the two methods of measuring the current was made when the humidity was. 75 per cent and they agreed to within 2

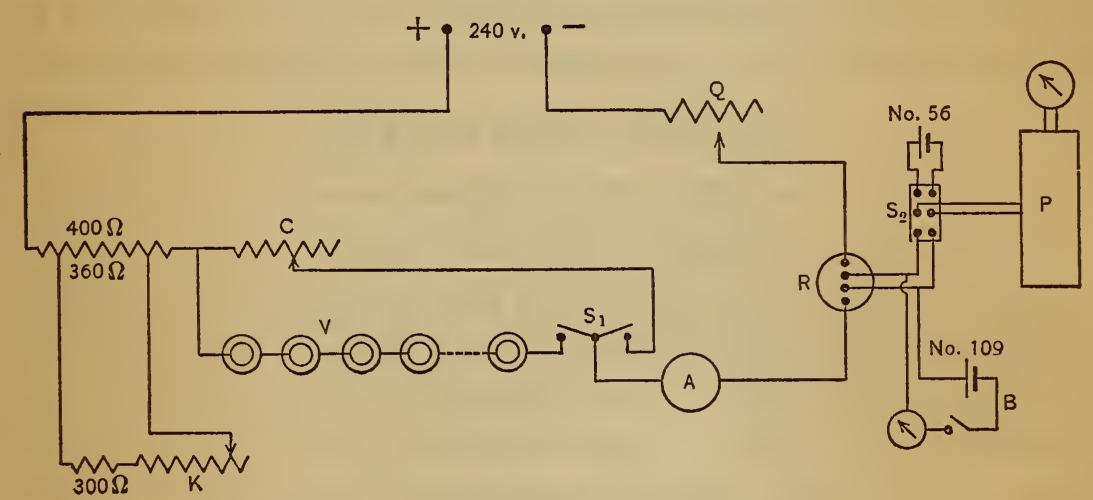

Fig 1.-The circuit

parts in I 000000 . All of the experiments were made under lower humidity conditions, and, when necessary, refrigerating coils were used to reduce the humidity of the room. A photograph, Fig. 2, shows the voltameters and some of the control apparatus.

As the potassium iodide solution in the iodine voltameters has a high temperature coefficient of conductivity and was subject to considerable heating by reason of its high resistance, some trouble was anticipated in maintaining the current at constant value, but this was avoided by immersing the iodine voltameters to a little above the $\mathrm{V}$ tube in large water baths. At the beginning of an experiment the drift in current due to heating in the voltameters was rapid for about five minutes, after which it decreased and 
finally became surprisingly steady during the greater part of the experiment.

Some of the experiments were at 0.25 ampere for four hours; in all of these except the first two the current was maintained constant during the experiment. In the other experiments a current of 0.05 ampere was used for 20 hours but the current was not measured against the standard cell and resistance. For the purpose of computing the value of the faraday it is not necessary to measure the current by cell and resistance. It was, however, deemed advisable to do so in some cases at least so that the silver voltameter determinations might be connected with previous work at the Bureau of Standards. For this purpose the same standard cell and resistances were again employed as in the previous investigation. Comparisons of these with the standards maintained at the Bureau showed only very slight changes to have taken place.

\section{THE VOLTAMETERS}

\section{A. THE IODINE VOLTAMETERS}

1. APPARATUS AND MANIPULATION

The three iodine voltameters used were of the same type as those previously employed by Washburn and Bates. The apparatus, which is shown in Fig. 3, consists essentially of two upright limbs connected by a $V$ tube. At the bottom of each $\operatorname{limb}$ is an electrode. The anodes consist of a platinum iridium alloy, it having been found that iodine is without appreciable effect on such an electrode, though one of pure platinum is attacked. Since the cathode solutions were not to be analyzed in the present investigation, it was permissible to use platinum electrodes for the cathodes. The electrodes were sealed into glass tubes, through which ran the electrical connections to the outside. These tubes as well as the capillary tubes through which the solutions were poured around the electrode come out through small openings in the caps at the top of the limbs. The joints between these tubes and the caps are made air-tight by means of short pieces of rubber tubing.

In order to prevent diffusion within the voltameter and also to prevent rapid changes in the resistance of the voltameters due to heating, the voltameters were placed in large water baths. 
The voltameter is first filled through the side tubes with a ro per cent solution of potassium iodide, which has been evacuated under an air pump to remove dissolved air. At the cathode side about ro cc of a concentrated solution of potassium iodide ( $\mathrm{g}$ salt to $\mathrm{I} g$ water) is then run down the capillary tube and this is immediately followed by about $20 \mathrm{cc}$ of a concentrated solution of iodine and potassium iodide, which completely covers the electrode. In a similar manner the anode is surrounded by about $25 \mathrm{cc}$ of the concentrated solution of potassium iodide.

At the conclusion of a run the solution in the cathode limb is discarded after having been sucked into a flask through the capillary and delivery tubes.

The amount of iodine formed at the anode by the passage of the current is determined by titration with a standard solution of arsenious acid. The theory of this titration and the calculation of the conditions which reduce the error to about o.oor per cent have been previously discussed. ${ }^{4}$ After the first rough weighing of one of the silver voltameters, the approximate quantity of electricity that has passed through the system, and hence the approximate amount of arsenious acid solution necessary for the titration, are calculated. An amount of the standard solution about one drop less than this is weighed out into a liter Erlenmeyer flask, and disodium phosphate solution added to control the hydrogen ion concentration. The flask is then fitted to the delivery tube so that the tip of the tube is below the level of the liquid and the anode solution quietly pulled up the capillary tube and over into the flask ("A," Fig. 2) by applying a gentle suction to the latter. The solution is then mixed and the titration completed in the manner described below.

\section{CHEMICALS AND SOLUTIONS}

The water employed for all of the solutions used in connection with the work of the iodine voltameter was obtained by redistilling the distilled water of the laboratory from alkaline permanganate, the first and last fractions of the distillate being discarded.

The potassium iodide was obtained by recrystallizing J. T. Baker's product until it was no longer alkaline to phenolphthalein. Because of the damp weather prevalent during this investigation, the potassium iodide was kept in desiccators over calcium chloride. 
The concentrated iodine solution which was used for surrounding the cathode was prepared by dissolving 9 ro $\mathrm{g}$ of $\mathrm{C}$. P. iodine and $585 \mathrm{~g}$ of potassium iodide in $320 \mathrm{~g}$ of water. The dilute standard iodine solution was prepared by diluting the concentrated solution till it was about o.or normal. Its strength was determined by titrating it against the dilute standard arsenious acid solution.

The standard arsenious acid solution was prepared by dissolving $240 \mathrm{~g}$ of Kahlbaum's arsenious acid which had been recrystallized from conductivity water in a solution containing $\mathrm{I} 20 \mathrm{~g}$ of $\mathrm{J}$. T. Baker's C. P. sodium carbonate. The solution was then made up to approximately 5 liters and kept in a 5 -liter glass bottle. The bottle was fitted with a delivery tube containing a stopcock and with a three-way tube through which hydrogen passed as the solution was withdrawn by means of the delivery tube. This three-way tube was attached to a manometer to indicate the pressure of hydrogen within the bottle and to Geissler bulbs which contained some of the same solution as was in the bottle and through which the hydrogen bubbled before entering the bottle.

It has been discovered in the previous investigation that the arsenious acid solution slowly oxidized. Hence, before beginning this investigation the solution was practically freed from dissolved air by slowly bubbling hydrogen through it. This was led in by means of the tube which afterwards served as the delivery tube, and which reached to the bottom of the bottle. After hydrogen has been bubbling through the solution for 24 hours, the stream of hydrogen was attached to the Geissler bulbs, care being taken that no air was permitted to enter the bottle. The pressure of hydrogen within the bottle was then raised to and maintained at a pressure equal to 4 or $5 \mathrm{~cm}$ of mercury greater than atmospheric pressure.

The hydrogen which was used for this purpose was prepared from C. P. zinc and sulphuric acid in a Kipp's generator. It was passed through a wash bottle containing alkaline permanganate and then over reduced copper contained in a quartz tube. This tube and the copper were kept red hot all the time during the course of this investigation by means of an electric heating device. From the quartz tube the hydrogen was led to the bottle containing the standard solution by means of a flexible copper tubing. 
The bottle was kept in a large tank or pail of about 20 liters capacity. This pail was filled with water to prevent condensation of moisture on the upper part of the inside of the bottle due to temperature changes in the surroundings. The whole was mounted on a turntable in such a manner that the delivery tube might be swung directly over the mouth of a flask resting on the pan of a large Rueprecht balance.

The dilute arsenious acid solution was prepared by diluting about ro $\mathrm{g}$ of the standard solution to roo times its weight. This solution was not protected from the air and since it slowly oxidized, a fresh lot was prepared every week or Io days. It was compared with the dilute iodine solution every three or four days; in this way it was possible to determine the strength of the solutions so that no error greater than 5 parts in I 000 ooo was introduced because of a change in their concentration.

\section{METHODS OF STANDARDIZATION AND ANALYSIS}

For the careful standardization of the arsenious acid solution, it was necessary to prepare a quantity of pure iodine. For this purpose potassium permanganate was added to an acid solution containing an excess of potassium iodide and the precipitated iodine after having been washed by decantation till the wash water was no longer acid, was dried in the centrifuge. It was then distilled from a retort and caught in a molten condition in a flask. The iodine was broken up in a dry mortar and kept in a desiccator over sulphuric acid, from there it was transferred as needed to the sublimation apparatus. This consisted of a Jena geräthe glass tube, Fig. 4, about Ioo $\mathrm{cm}$ long and $3 \mathrm{~cm}$ diameter. Into one end of it fitted a ground-glass stopper through which a current of air could be passed. This air was bubbled through a solution of alkaline permanganate, through two wash bottles containing sulphuric acid and then passed through a tube containing phosphorus pentoxide which had been recently sublimed into it. At the end nearest to the subliming apparatus this tube was closed by means of a stopcock, which was joined with Khotinski cement to the glass stopper of the subliming tube. During the course of the experiments very little moisture reached the phosphorus pentoxide and that only at the end farthest from the subliming apparatus. 
The iodine in a porcelain boat is placed inside the sublimation apparatus at $\mathrm{S}$ just ahead of the glass stopper. Movable heating coils of manganin wire serve to sublime the iodine from this position down the length of the tube. The rate of sublimation could be conveniently controlled by regulating the temperature of the heating coils and the current of air passing through the tube. In passing from one end to the other of the sublimation apparatus the iodine was sublimed at least three times. It was then transferred without exposure to the atmosphere of the room, into a previously weighed quartz weighing bottle $B$, by means of the rake $R$ which was operated through a narrow tube some $40 \mathrm{~cm}$ in length sealed onto the subliming tube.

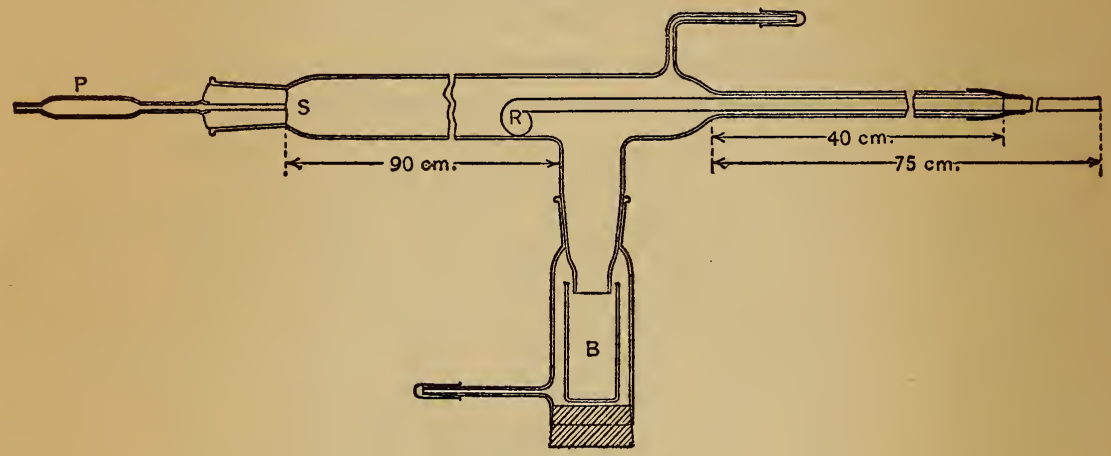

Fig. 4.-Sublimation apparatus

The iodine was weighed in the constant temperature room on the Oertling balance which has been previously described. ${ }^{5}$ When empty the weighing bottles were always left on the balance pan at least four hours before a weighing was attempted, when they contained iodine they were left over night. The weighings were made by substitution, an empty weighing bottle serving as part of the counterpoise. The set of weights employed had been compared with the standard weights of the Bureau. It is believed that the weight of iodine was known to $0.02-0.03 \mathrm{mg}$.

For the first week or two of the present investigation the iodine voltameters did not check well and the arsenious acid solution could not be accurately standardized. It was found that the trouble lay in the method of weighing the solution. Up to June 26 the 
method was that employed in the previous investigation at the University of Illinois. Liter Erlenmeyer flasks were balanced on the two pans of a large Rueprecht balance, the desired amount of solution run into the flask on the left-hand pan, a rubber stopper which had been weighed with the flask inserted into its mouth and the weight of the added solution accurately determined. The previous work had been done during the spring of the year in a basement room which was not heated artificially. The room was quite cool and the variation in the amount of evaporation of the solution during the time required to draw off the solution and stopper the flask was not rapid enough to introduce an error greater than 0.002 per cent. The temperature of the room in which the weighings for the present investigation were made was between $29^{\circ}$ and $31^{\circ} \mathrm{C}$. This caused an uncertainty in the weighing which depended upon the length of time it took to transfer the proper amount of solution to the flask and to stopper it. This time was somewhat variable, since toward the end of the addition of the solution to the flask it had to be added slowly in order to get the weight within $0.1 \mathrm{~g}$ of that required for the titration, before the final weighing to a few tenths of a milligram was attempted.

This uncertainty in the weight of the standard solution was greatly reduced by the following modification in the method of weighing. About $25 \mathrm{cc}$ of water was added to both of the flasks on the balance pan, they were then balanced and it was determined whether or not the rate of evaporation of water from both of them was the same. The mouth of the counterpoise flask was somewhat larger than that of the flasks in which the solution was weighed, so it lost weight more rapidly. However, by adjusting the size of the opening by means of a small piece of paper, the rate of evaporation from the two flasks could be practically equalized.

The required amount of solution was then added, both flasks left unstoppered, and the weight determined as soon as possible. The rate of evaporation was again investigated, and if it were not the same as it was before the solution was added, an allowance was made for this. The uncertainty in the weight of solution taken was seldom over $0.5 \mathrm{mg}$, but is probably the greatest source of error connected with the iodine voltameters in this inves- 
tigation. With practice this error was reduced, since toward the end of this investigation both the voltameters and the standardizations checked to $\mathrm{I}$ or 2 parts in 100000 .

After the arsenious acid solution was weighed out, the required amount of disodium phosphate solution was added to the flask. In the case of the standardizations some $30 \mathrm{~g}$ of potassium iodide was also added, and then the quartz weighing bottle was introduced into the flask and opened below the level of the liquid to prevent any loss of iodine vapor. When the iodine had completely dissolved, water was added till the volume of the solution was 250 to $275 \mathrm{cc}$.

The dilute arsenious acid solution was then run from a burette into the flask till the iodine color all but disappeared and the solution set aside for three to five minutes for equilibrium conditions to be attained. For the completion of the titration the flask containing the solution and another containing the same volume of water were set side by side on a large sheet of unglazed white paper before a north window. The arsenious acid solution was then added drop by drop till the iodine color just disappeared. It was possible by proceeding in this way and by comparing the appearances of the liquids in the two flasks to detect the effect of a single drop of the arsenious acid solution upon the iodine color. After determining the end point, about I cc of the dilute iodine solution was run in and the end point again determined. In this way three or more observations were always obtained for each end point; with practice and with favorable illumination it was possible to decrease the uncertainty in the end point to $0.02-0.03 \mathrm{cc}$ of the dilute arsenious acid solution. This corresponds to an uncertainty in the titration of 5 or 6 parts per 1000000 .

In order to get the iodine formed at the anode of the voltameter into a flask to be analyzed, a rubber stopper carrying the delivery tube was fitted to the flask containing the arsenious acid solution and the phosphate solution, in such a way that the end of the delivery tube dipped below the surface of the liquid. (Fig. 2.) The flask was then supported beside the voltameter and the delivery tube connected to the bulb at the top of the capillary tube by means of the ground glass joint. On applying a gentle 
suction to the flask the anode portion was sucked over, the last visible trace of iodine from around the electrode disappearing up the capillary by the time half of the solution contained in the anode limb had been sucked over into the flask. As a precaution, however, the entire anode solution was used to wash out the capillary and delivery tubes. The solution was then thoroughly mixed and the titration completed as described above.

\section{STRENGTH OF THE STANDARD ARSENIOUS ACID SOLUTION}

The data obtained for the standardization of the arsenious acid solution are given in Table $\mathrm{I}$. This table is divided into two parts, corresponding to the two methods of weighing the solution. The first column gives the date of the standardization, the second the number of grams of iodine taken (corrected to vacuo by adding 0.0099 per cent of the apparent weight). In the third is found the number of grams of arsenious acid solution used in the titration; the fourth gives the grams of iodine corresponding to I gram of the standard solution; this value will hereafter be referred to as the factor. The value for the factor, as calculated in the manner described below, is given in the next column, and in the sixth is found the difference in per cent between the value of the factor as found and as calculated.

The results show that even with the precautions taken the standard solution was oxidizing. In order to compare the standardizations and to determine the strength of the solution at any time the values of the factor found in column 4 were plotted against the corresponding days upon which the titrations were performed. It was found that for the period during which the second and more accurate method of weighing was employed a straight line could be drawn through the points in a satisfactory manner. From this line the strength of the solution for any particular day may be read off or the factor may be calculated from the equation of the line. The value for the factor $F$ on the $t^{t h}$ day after June 30 is given by $\mathrm{F}=0.1081352-0.00000096 \mathrm{t}$, and therefore changes at a rate less than 0.00 I per cent per day. The values for the factor given in the fifth column of Table I were calculated by means of this equation. 


\section{TABLE 1}

\section{Standardization of Arsenious Acid Solution}

\section{FIRST PERIOD}

\begin{tabular}{|c|c|c|c|c|c|}
\hline Date & Iodine & $\begin{array}{l}\text { Arsenious } \\
\text { acid } \\
\text { solution }\end{array}$ & $\begin{array}{l}\text { Factor } \\
\text { found }\end{array}$ & $\begin{array}{c}\text { Factor } \\
\text { calculated }\end{array}$ & $\begin{array}{c}\text { Difference } \\
\text { in per } \\
\text { cent }\end{array}$ \\
\hline 1913. & & & & & \\
\hline June $4 \ldots \ldots \ldots \ldots \ldots . . . . .$. & 4.81605 & 44.5100 & 0.108201 & 0.108193 & +0.008 \\
\hline June $7 \ldots \ldots \ldots \ldots \ldots$ & 5.11905 & 47.3058 & 212 & 190 & +0.020 \\
\hline June $11 \ldots . . . \ldots \ldots . . . .$. & 4.97658 & 46.0003 & 186 & 186 & 0.000 \\
\hline June $14 \ldots \ldots \ldots \ldots . . .$. & 2.89043 & 26.7085 & 221 & 183 & $+(0.035)$ \\
\hline June $16 . . . \ldots \ldots \ldots . . .$. & 5.96126 & 55.1136 & 163 & 180 & -0.016 \\
\hline June $19 . . . . . . . . . . . .$. & 4.13730 & 38.2395 & 220 & 178 & $+(0.039)$ \\
\hline June $21, \ldots \ldots \ldots \ldots \ldots$ & 4. 78222 & 44. 2131 & 163 & 176 & -0.012 \\
\hline Average deviation. & & & & & 0.011 \\
\hline
\end{tabular}

\section{SECOND PERIOD}

\begin{tabular}{|c|c|c|c|c|c|}
\hline Date & Iodine & $\begin{array}{l}\text { Arsenious } \\
\text { acid } \\
\text { solution }\end{array}$ & $\begin{array}{l}\text { Factor } \\
\text { found }\end{array}$ & $\begin{array}{l}\text { Factor } \\
\text { calculated }\end{array}$ & $\begin{array}{l}\text { Difference } \\
\text { in per } \\
\text { cent }\end{array}$ \\
\hline 1913. & & & & & \\
\hline June $30 . \ldots \ldots \ldots \ldots \ldots$ & 5.80150 & 53.6502 & 0.1081356 & 0.1081352 & +0.0004 \\
\hline 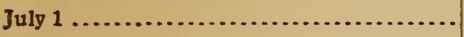 & 5.73071 & 52.9967 & 334 & 343 & -0.0008 \\
\hline 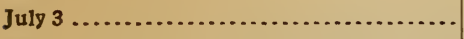 & 5.39535 & 49.8957 & 326 & 323 & +0.0003 \\
\hline July $9 \ldots \ldots \ldots \ldots \ldots \ldots \ldots \ldots \ldots \ldots \ldots \ldots \ldots \ldots$ & 4. 50081 & 41.6258 & 254 & 266 & -0.0011 \\
\hline July $10 \ldots \ldots \ldots \ldots$ & 5.41817 & 50.1110 & 233 & 256 & -0.0021 \\
\hline July $12 \ldots \ldots \ldots \ldots$ & 4.64987 & 43.0048 & 244 & 237 & +0.0006 \\
\hline July $16 \ldots \ldots \ldots \ldots$ & 5.37630 & 49. 7256 & 197 & 199 & -0.0002 \\
\hline Juk $17 \ldots \ldots \ldots$ & 5.98294 & 55.3427 & 071 & 189 & $-(0.0109)$ \\
\hline July $19 \ldots \ldots \ldots$. & 5.78941 & 53.5518 & 086 & 170 & $-(0.0077)$ \\
\hline July $21 \ldots \ldots \ldots \ldots$ & 4.93161 & 45.6139 & 163 & 151 & +0.0011 \\
\hline July $22 \ldots \ldots \ldots \ldots$ & 5.00639 & 46.3064 & 144 & 141 & +0.0003 \\
\hline July $23 . . . \ldots \ldots$ & 5.31224 & 49.1342 & 169 & 132 & +0.0033 \\
\hline July $25 \ldots \ldots \ldots$ & 5.15089 & 47.6395 & 222 & 112 & $+(0.0101)$ \\
\hline July $28 \ldots \ldots \ldots$. & 4.91674 & 45.4787 & 108 & 083 & +0.0023 \\
\hline July $29 \ldots . . . .$. & 4. 70907 & 43.5590 & 078 & 074 & +0.0004 \\
\hline July $30 \ldots \ldots \ldots$ & 5.77480 & 53.4188 & 042 & 064 & -0.0020 \\
\hline July $31 \ldots \ldots \ldots . . . .$. & 4.31213 & 39.8883 & 051 & 054 & -0.0003 \\
\hline August $1 \ldots \ldots .$. & 5.18195 & 47.9361 & 012 & 045 & -0.0030 \\
\hline August $2 \ldots \ldots \ldots$. & 5.55903 & 51.4236 & 027 & 036 & -0.0008 \\
\hline Average deviation.. & & & & & 0.0012 \\
\hline
\end{tabular}


Of the standardizations obtained by the second method of weighing, those of July 17,819 , and 25 were not considered in placing the line, because they deviated widely from the other observations. That of July I 7 is furthest from the calculated value, the difference being o.o I per cent.

The average deviation of o.00I 2 per cent is about what would be expected from the uncertainties in weighing the iodine, in weighing the solution, and in determining the end point.

For the first period, during which the method of weighing was unsatisfactory, it is extremely difficult to draw a line in a manner similar to that drawn for the second period. The slope of such a line, however, should be the same as that for the second period, since the change in the method of weighing could not have influenced the rate of oxidation of the solution. Having thus obtained the slope of the line, its position was chosen so that the positive and negative deviations were equal. The value for the factor for this first period was determined graphically.

\section{B. THE SILVER VOLTAMETER}

1. FORMS USED

Two forms of silver voltameter were used in all experiments, Smith's new form and the porous cup form. Both of these have been described in detail elsewhere. ${ }^{6}$ They are shown photographically in Fig. 2. In the tables that follow in the next section it will be seen that the results of the absolute runs made with these voltameters are in good agreement with the best previous work. As in the case of the third series of experiments published by Rosa, Vinal, and McDaniel, ${ }^{6}$ where the mean value of the Weston normal cell is given in terms of both forms of voltameters, so here we have included in the mean both forms of voltameters to obtain the value of the silver with which to compare the mean iodine deposits.

2. MATERIALS, ETC.

The details of the manipulation of the voltameters and the preparation of materials have all been described before. ${ }^{7}$ The electrolyte was prepared from double-distilled water and silver nitrate especiallly prepared and tested for acidity by iodeosine and for reducing agents by potassium permanganate as described by Rosa, Vinal, and McDaniel. ${ }^{8}$ The anode and cathode acidi- 
ties of each voltameter were measured at the conclusion of the experiment. The mean acidity of the electrolyte at the beginning of the experiment and the cathode acidity at the end of the experiment were thus determined for each voltameter and corrections to the deposit could be made for the acid present according to the equation $\mathrm{Y}=4.5 \mathrm{X}$ where $\mathrm{Y}$ is the amount to be added to the deposit in parts per million and $\mathrm{X}$ the acidity of the electrolyte in parts per million. This correction was determined by Rosa, Vinal, and McDaniel and is described by them. In the present case the electrolyte was always very nearly neutral so that the corrections are very small in all cases.

\section{TABLES OF RESULTS}

The details of each experiment made or attempted are given in Table 2. The experiment of June 6 which is designated as No. I we have omitted from the summary of results contained in Table 3 since during the run iodine from the cathode was seen to have migrated up this limb and over into the anode side, coloring the liquid in the connecting V-tube quite distinctly. ${ }^{9}$ Before starting the experiment it had been suggested that the first run would be largely of a preliminary nature. Aside from this run the only silver voltameter measurements omitted in computing the results are those enclosed in brackets. One of them on July 22 deviates from the mean by about four times the average deviation of theothers and hence may be called a gross error. Two others, on July 30 , were found to be alkaline at the close of the experiment which is sufficient reason to discard them as shown in previous investigations. ${ }^{10}$ Owing to a miscalculation which resulted in much too little arsenious acid solution being weighed out for two of the voltameters of run No. 9, but one accurate analysis of the iodine formed in this experiment was obtained.

In the column of remarks the experiments designated as "absolute" are those in which the current was maintained constant during the entire time of the run and measured in terms of a standard cell and resistance. In the "comparative" experiments this was not done.

\footnotetext{
9 This movement was prevented in subsequent runs by the addition of the few cubic centimeters of concentrated potassium iodide solution which was run into this limb just before the iodine solution. With this procedure, it was never possible to detect any coloration due to iodine more than one-third way up the cathode limb.

10 Report of Int. Tech. Com., p. I57.
} 


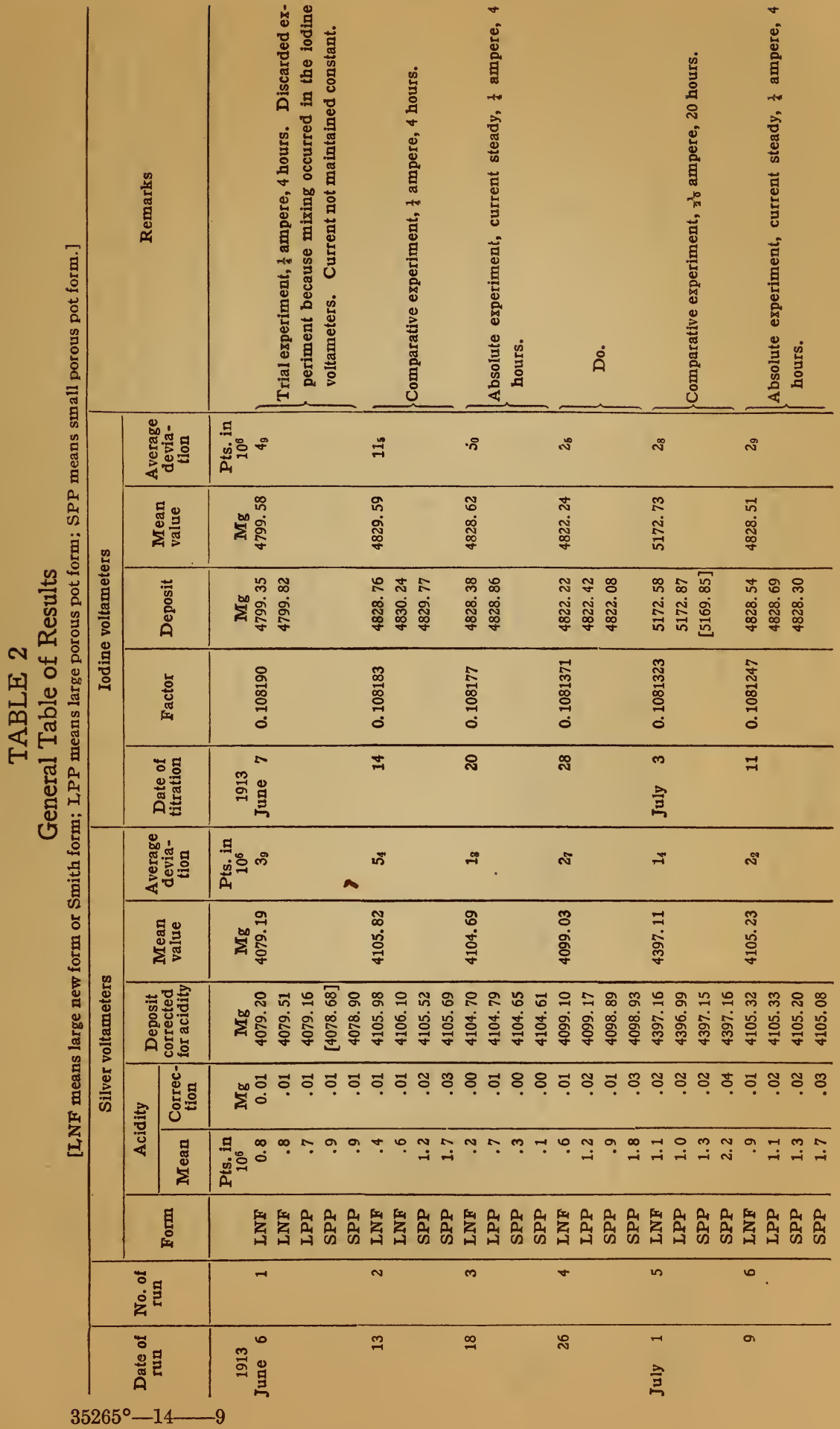




\begin{tabular}{|c|c|c|c|c|c|c|c|c|}
\hline & & 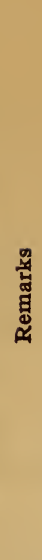 & & 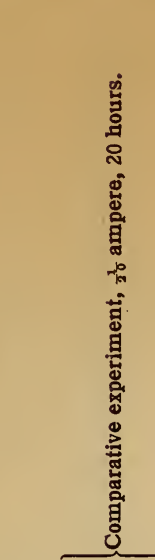 & 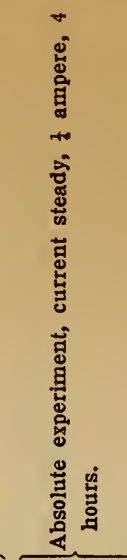 & 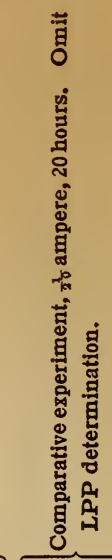 & 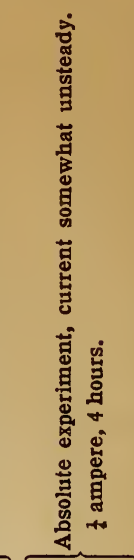 & 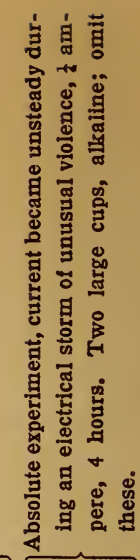 \\
\hline & & & & 焉员 & 8 & & $\Rightarrow$ & $=$ \\
\hline 胥 & gू & & 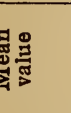 & 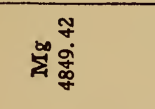 & 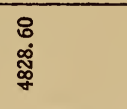 & $\begin{array}{l}\text { o } \\
\stackrel{\vec{J}}{\text { J }}\end{array}$ & $\begin{array}{l}\text { f } \\
\stackrel{\tilde{\Xi}}{\text { J }}\end{array}$ & 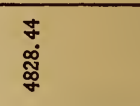 \\
\hline 远 & 这 & & 䓂 & 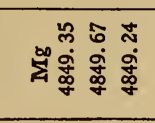 & 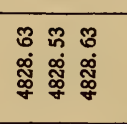 & 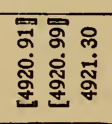 & 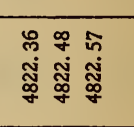 & 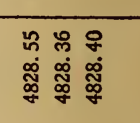 \\
\hline 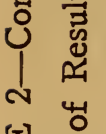 & 旁 & & 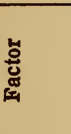 & $\begin{array}{l}a \\
\stackrel{9}{0} \\
\stackrel{0}{0} \\
0\end{array}$ & $\stackrel{\substack{: \\
:}}{\stackrel{0}{0}}$ & $\begin{array}{l}\mathbb{Z} \\
\mathbb{0} \\
\stackrel{0}{0} \\
0\end{array}$ & $\begin{array}{l}\text { : } \\
\stackrel{0}{0} \\
\stackrel{0}{0}\end{array}$ & $\begin{array}{l}\text { पे } \\
\text { 惫 } \\
\stackrel{0}{0} \\
0\end{array}$ \\
\hline 点 & & & 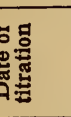 & 哭 & 9 & $\overline{\mathrm{N}}$ & 8 & $\overrightarrow{\text { ले }}$ \\
\hline त్త్ర & & & 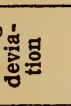 & 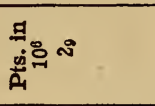 & 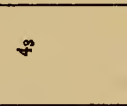 & $\approx$ & a & $\infty$ \\
\hline & & & : & 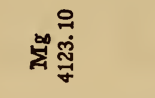 & 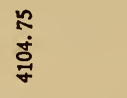 & 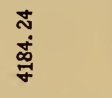 & 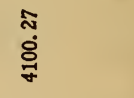 & $\begin{array}{l}\stackrel{9}{0} \\
\stackrel{8}{\sigma}\end{array}$ \\
\hline & & & 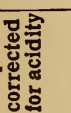 & 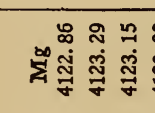 & 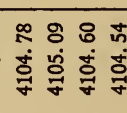 & 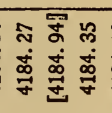 & 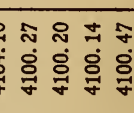 & 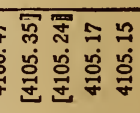 \\
\hline & 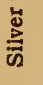 & & 这哭 & 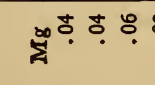 & 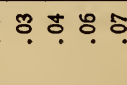 & !ั & ب. & \begin{tabular}{l:l}
3 & $\vdots$ \\
\hdashline & $\vdots$
\end{tabular} \\
\hline & & $\frac{\pi}{4}$ & 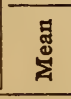 & 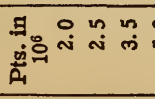 & 웡 & $\begin{array}{ll}0 \\
\vdots \\
\vdots \\
\vdots\end{array}$ & $\div 90 \div$ & 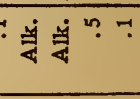 \\
\hline & & & 罟 & 舀畣会 & 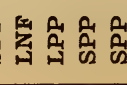 & 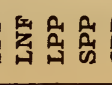 & 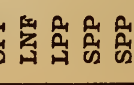 & 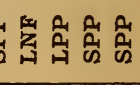 \\
\hline & & ö & & N & $\infty$ & $a$ & 움 & $\Rightarrow$ \\
\hline & & 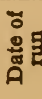 & & 塄志 & $\stackrel{\infty}{\sim}$ & ส & 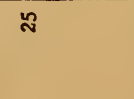 & 8 \\
\hline
\end{tabular}


In Table 3 are contained the summarized results and the computed values for the ratio of silver to iodine, the electrochemical equivalent of iodine, and the value of the faraday. Column I gives the number of the experiment corresponding to the numbers given in Table 2. Columns 2 and 3 contain the mean deposits of silver and iodine for each experiment. Under "calculated coulombs" we give the number of coulombs as calculated from the silver voltameter deposits, using the value r. I $800 \mathrm{mg}$ per coulomb as defined by the London conference. These are therefore in international units. We also give the coulombs as calculated from the measurement of current and time when the absolute runs were made. These also are international unit coulombs, since they have been computed on the basis of the Weston normal cell taken as 1.0183 volts at $20^{\circ} \mathrm{C}$ and the international ohm. The differences between these are given in the next column. On the average the coulombs calculated from the voltameter are $\frac{I .5}{100000}$ smaller than from the measurements of current and time. This is as it should be, since the voltameter measurements at the Bureau of Standards recently have given a value for the cell about 2 or 3 parts in roo ooo lower than the adopted value r.or83. The slight ambiguity that arises in the term "international coulombs," due to the possibility of measuring them in terms of the silver voltameter and time, or in terms of the international ohm, volt, and time, is fully explained in Part IV of the series of papers by Rosa, Vinal, and McDaniel. ${ }^{11}$ For the present purposes this difference is immaterial, because in computing the value of the faraday the international atomic weight for iodine is involved, which is expressed to only five significant figures.

The system used in weighting the several experiments was purely mathematical, based upon the fact that for each result the error is due to the combination of experimental errors entering from the value of the factor for the arsenious acid $\left(z_{1}\right)$, from the titration of the iodine deposits $\left(\mathrm{z}_{2}\right)$, and finally from the determination of the silver $\left(z_{3}\right)$. The final result $Z$ is then a function of these three quantities, $Z=f\left(z_{1} z_{2} z_{3}\right)$. 
We may easily compute the probable errors of each of these factors from the average deviation. If we designate them as $r_{1} r_{2} r_{3}$ the probable error of the result of the experiment is given by

$$
\mathrm{R}^{2}=\left(\frac{\delta Z}{\delta \mathrm{z}_{1}}\right)^{2} \mathrm{r}_{1}{ }^{2}+\left(\frac{\delta Z}{\delta \mathrm{z}_{2}}\right)^{2} \mathrm{r}_{2}{ }^{2}+\left(\frac{\delta Z}{\delta \mathrm{z}_{3}}\right)^{2} \mathrm{r}_{3}{ }^{2}
$$

TABLE 3

Summary of Results

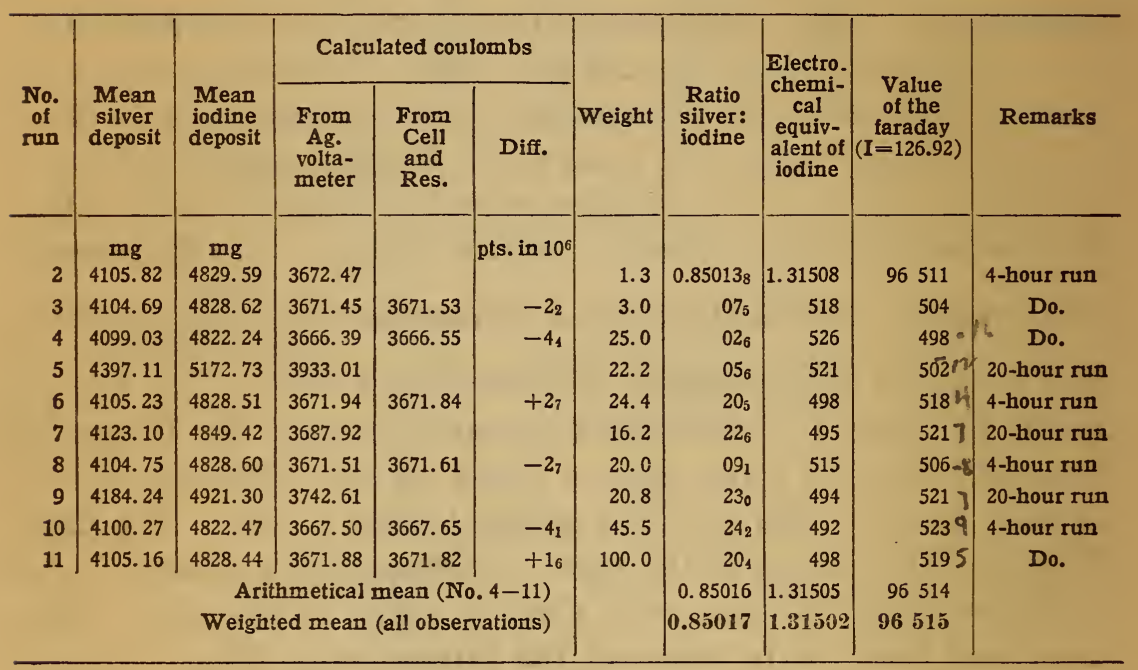

These calculations have been carried out and weights computed inversely as the square of the probable error. Some system of weighting seemed to be necessary since the later experiments were deemed more reliable than the earlier ones. The experiments numbered 2 and 3 have very small weights, owing to the difficulties in weighing out the arsenious acid at this time, so that they may practically be disregarded. We give the arithmetical mean of experiments 4 to I I for comparison with the weighted mean. The differences are very small. 


\section{DISCUSSION OF RESULTS}

\section{A. THE SILVER-IODINE RATIO}

In Table 3 the results of this investigation have been presented in three ways-(I) as the ratio of silver to iodine, (2) as the electrochemical equivalent of iodine, and (3) as the value of the faraday calculated from the iodine voltameter. The ratio has been given chiefly because it possesses certain advantages for discussing the results. If the increase in weight of the platinum bowls used as cathodes represented only the weight of silver electrolytically changed from the simple $\mathrm{Ag}+$ ions to metallic silver, and if the only reaction taking place at the anode of the iodine voltameter is the formation of iodine from iodide ions under the action of the current, then according to Faraday's law the amounts of silver and of iodine so found are in the ratio of the atomic weights of the elements.

Baxter, ${ }^{12}$ who has made a very careful study of the atomic weights of silver and of iodine, as the result of early work gave 0.849997 as the value of this ratio. As a result of further work he arrived at the result $0.849930,{ }^{13}$ and more recently from a series of very concordant experiments he found the value $0.849906 .{ }^{14}$ That calculated from the international atomic weights (1914) for silver and iodine, which are largely founded on Baxter's results, is 0.84998. The only other investigation of recent years which is comparable with the results of Baxter is that of Köthner and Amer, ${ }^{15}$ who determined the silver-iodide silver-chloride ratio in eight closely agreeing analyses. Their result, on the basis of chlorine 35.457 , gives 0.850013 as the value of the silver-iodine ratio.

It is not our purpose to discuss these atomic weight determinations. It is evident that our determination of the silver-iodine ratio is from 0.015 to 0.030 per cent higher than that calculated from purely chemical methods. It seems unlikely that further work employing the same chemical reactions as have been hitherto

\footnotetext{
12 Carnegie Public. No. I35, p. Ior.

13 Ibid., p. 108.

$14 \mathrm{~J}$. Am. Chem. Soc., 32, p. I59I (I9ro).

16 Ann. d. Phys., 337, pp. 123, 362 (r904).
} 
used would cause this discrepancy to disappear, although Baxter considers that further evidence upon the silver-iodine ratio is desirable.

Our consistently higher results are in the direction of too heavy a deposit of silver or the formation of an insufficient amount of iodine. It may readily be suggested that the difference may be in part accounted for by inclusions of liquid in the silver deposit, but the conflicting results of previous observers do not permit us to estimate the amount. The last work by Laird and Hulett ${ }^{16}$ indicates that deposits from pure solution probably do not contain more than 0.005 per cent inclusions. The whole question of inclusions is critically discussed by Rosa, Vinal, and McDaniel. ${ }^{17}$ Their opinion is that the deposits so perfectly crystalline as formed from the purest $\mathrm{AgNO}_{3}$ obtainable do not contain significant inclusions. It is hoped that the work being carried out on this important subject in several laboratories will definitely settle the matter shortly.

In connection with the iodine voltameter three possible sources of error suggest themselves.

I. The main reaction which takes place at the anode, resulting in the formation of iodine from iodide ions, may have been accompanied by another electrochemical reaction, such as the formation of oxygen which then remained dissolved in the solution.

2. Sufficient iodine may have been formed, but a slight amount of it reacted with the water or with the metal of the electrodes.

3. The iodine used to standardize the arsenious acid solution may not have been suffciently pure.

In the first place there is no certain difference between the results obtained using the current strengths of 0.05 ampere and of 0.25 ampere. The arithmetical means differ by 0.002 per cent while the weighted means differ in the opposite direction by 0.003 per cent. This shows that there is no appreciable error arising from such a reaction as the electrolytic formation of oxygen, for such a reaction would evidently be much greater with the higher current densities.

${ }_{16}$ Trans. Am. Electrochem. Soc., 22, p. 345; x9r2.

17 This Bulletin, 10, I913, Reprint No. 220. (In press.) 
Secondly, had any of the iodine been lost by reacting with the platinum-iridium electrodes this fact would have been immediately noticed, for it was found in the previous investigation that the presence of the slightest trace of platinum-less even than that corresponding to a loss of o.oor per cent iodine-so affected the color of the solution that the end point in the titration was quite uncertain.

In solutions of iodine which contain in addition potassium iodide, as did all of our solutions, the iodine exists almost entirely as the triiodide ion, $\mathrm{I}_{3}{ }^{-}$. Iodine may react with water in two ways; these may be most conveniently expressed in the ionic forms,

$$
\mathrm{OH}^{-}+\mathrm{I}_{3}^{-}=\mathrm{HIO}+2 \mathrm{I}^{-}
$$

and

$$
6 \mathrm{OH}^{-}+3 \mathrm{I}_{3}^{-}=\mathrm{IO}_{3}^{-}+8 \mathrm{I}^{-}+3 \mathrm{H}_{2} \mathrm{O} \text {. }
$$

The equilibrium constants of these two reversible reactions have been calculated. ${ }^{18}$ In accordance with these calculations the conditions of the titrations in the present investigation were so regulated, by controlling the hydroxyl ion concentration, that when equilibrium was attained, no appreciable amount of hypoiodite or of iodate were present. The calculations showed that even with a rather large variation of the hydroxyl ion concentration an amount of iodine less than o.oor per cent would be lost. This was confirmed experimentally by adding different amounts of sodium phosphate to some of the solutions which were being analyzed. In this way the hydroxyl ion concentration was varied about fiftyfold. Such a change had no noticeable effect on the end point, that is, it affected the analytical results by less than o.oor per cent.

The best evidence that the combined effect of errors due to the formation of electrolytic oxygen and to the loss of iodine through side reactions is negligible was obtained in the previous investigation on the iodine voltameter.

The reaction which takes place at the cathode of the voltameters is the formation of iodide ions from iodine, being just the reverse of that occurring at the anode. Hence, in order to determine the silver-iodine ratio or to calculate the Faraday it is just as feasible theoretically to employ the amount of iodine used up at the cathode as it is to employ the amount formed at the anode. In the previous investigation both of these amounts of iodine were 
determined, and it was found that they agreed with one another within the experimental error of 0.003 per cent. That is, within this limit no side reactions resulting in the formation of too little iodine at the anode occur; the reaction taking place at the electrodes is strictly reversible. The amount of iodine used up at the cathode was not determined in the present investigation because the analysis of the cathode solution is much more difficult experimentally than is that of the solution at the anode.

Thirdly, if any of this discrepancy between the silver-iodine ratios is to be ascribed to impurity in the iodine, this impurity would have had to consist of some oxidizing substance having a smaller equivalent weight than has iodine. The presence of an inert substance such as moisture would have caused a deviation in a direction opposite to that actually found. Special precautions were taken to eliminate from the iodine any oxidizing substance, such as bromine. As described above, the iodine was precipitated by means of potassium permanganate from a solution containing an excess of potassium iodide. The partly dried iodine was then distilled from a retort and caught in a molten condition, and finally it was repeatedly sublimed in a current of dry air. Any one of these three procedures should have practically eliminated any trace of chlorine or bromine which might have been present. The last step, the fractional sublimation, was carried out separately each time the arsenious acid solution was standardized. The procedure was not always the same; occasionally but three sublimations were employed, but more often five or six. It is scarcely possible that under such circumstances an amount of volatile impurity sufficient to account for an appreciable part of the discrepancy of (o.01 5 to 0.03 per cent) should have remained so constant in amount that the average deviations of the standardizations (see Table I) were but 0.0012 per cent, an amount easily accounted for by experimental error.

Taking these various sources of error into consideration, it is probable that the amount of iodine calculated to have been found at the anode is within 0.005 per cent of that corresponding to the electrochemical change of iodide ions to iodine. The calculations of the value of the Faraday from this involves the atomic weight of iodine and the electrical measurements of the present investi- 
gation. It seems unlikely that the mean value for the Faraday ( $965_{5} 4$ international coulombs) given in Table 3 is in error by more than o.or 5 per cent.

The possibility of electrical leakage on the voltameter stands being a source of error was also considered, but tests easily made showed the insulation to be amply sufficient.

\section{B. THE FARADAY}

If the increase in weight of the platinum bowls of the silver voltameter be assumed to represent only the metallic silver formed from silver ions, then taking the atomic weight of silver as 107.88, the Faraday is defined as $\frac{107.88}{.00111800}=96494$ international coulombs. From the iodine voltameter we obtained the value $965^{1} 4$; the mean, 96504 , probably represents within o.or per cent the true value in international units.

Values in absolute units.-For theoretical purposes it is desirable that the value of the Faraday should be known in absolute units. We do not, however, think it advisable to emphasize this value at the present time, for the following reasons:

I. Electrical measurements are almost universally made at the present time in terms of the international units as maintained by the several national laboratories.

2. Recent absolute measurements of the electrochemical equivalent of silver made in several countries differ somewhat among themselves, and therefore it is necessary to state explicitly what is the basis of any computations that one might make. This is not the case with the international units.

3. It is probable that the difference between the absolute electrochemical equivalent of silver and the value I.I 800 adopted for the basis of the international ampere is as small as the uncertainties in the atomic weights of silver and iodine which are involved in the computation of the Faraday. .

A recent investigation at the Bureau has given for the electrochemical equivalent of silver I.II804 mg per absolute coulomb. Hence, the absolute coulomb is 0.004 per cent greater than the international coulomb, or the faraday in absolute units is less by this amount. In absolute units the rounded off figure 96500 , seems the best value to assign, for the present, to this constant. 


\section{COMPARISON WITH PREVIOUS INVESTIGATIONS}

\section{A. SILVER VOLTAMETER}

The present results with the silver voltameter are most easily compared with past work by considering the values computed for the Weston Cell at $20^{\circ}$ for the experiments in which the current was controlled. These experiments are called "absolute experiments" in Table 2 . In Table 3 we gave the coulombs as calculated from the silver deposits and also from the measured current and time. We noted in the discussion of this table that the first method gave a lower value on the average than the second by $\frac{1.5}{100000}$ which is significant of the difference between the exact value for the cell I.OI827 recently found by the voltameter and the figure adopted for use by the international committee I.OI 83 volts. It is evident then that the present work has given the value I.OI $828_{5}$ for the cell value. This is perhaps more readily seen by computing the cell value for each silver voltameter deposit in an absolute experiment and taking the mean. Having done this we find the average value from Smith's new form of voltameter to be $I .01828_{9}$ and from the porous cup voltameter to be I.or $828_{0}$ whence the result $1.01828_{5}$ as given above. The value 1.01827 given as the result of previous work is based on 2 I I deposits made with the greatest care by Rosa, Vinal, and McDaniel. It thus appears that the present work agrees with the past to o.00I 5 per cent.

\section{B. IODINE VOLTAMETER}

In their investigation Washburn and Bates made a preliminary comparison of the silver and iodine voltameters. The relation between their results and ours is more readily discussed in terms of the silver-iodine ratio than by means of the value for the faraday calculated from the iodine voltameter. This is because their value for the faraday involves Smith, Mather, and Lowry's absolute determinations using the filter paper voltameter. For the silver iodine ratio Washburn and Bates obtained the value 0.85045 , which is 0.033 per cent higher than that recorded here. This difference is due to the fact that following the specifications of Smith, Mather, and Lowry, they employed the filter paper form of silver voltameter. Recent investigations at the Bureau of 
Standards have shown conclusively that deposits obtained in such a voltameter are too heavy, because of the action of the filter paper. Hence, in order to compare the previously obtained ratio with that given, here, it is necessary to compare the filter paper voltameter with those forms used in the present investiation.

The silver voltameters we employed were of the porous cup and nonseptum types. The electromotive force of the Weston normal cell at $20^{\circ}$, calculated from deposits made in such voltameters is I.0I $827^{19}$ volts. With the filter paper form the value I.or $866^{20}$ was obtained; that is, the deposit in such a voltameter is about 0.038 per cent heavier than that obtained in the types used in the present investigation. Making the percentage correction to the silver iodine ratio determined by Washburn and Bates, the value 0.85013 is obtained, which agrees within 0.005 per cent with our final value. This agreement is probably in part accidental, since the filter paper voltameter is, in the hands of various investigators, scarcely capable of such reproducibility, and since in the previous investigation an accuracy better than 0.02 per cent was not claimed for the final value, which was founded on but four comparative runs. It does, however, confirm the belief that our results are not in error by more than o.or per cent.

\section{SUMMARY}

We have made a careful comparison of the silver and iodine voltameters, using them in series so that the deposits of silver and iodine should be strictly comparable. The best procedure learned from previous investigations has been followed in each case. Our results are as follows:

x. Ratio of silver to iodine..................... o. 85017

2. Electrochemical equivalent of iodine .............. I. 31502

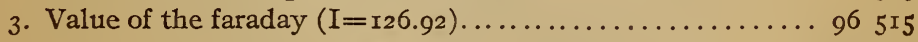

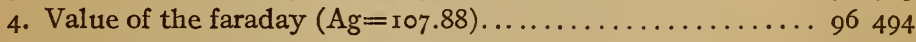

5. Value recommended for general use................ 96500

Nos. 2, 3, and 4 are calculated on the basis of the international ampere, using I.II800 $\mathrm{mg}$ per coulomb as the electrochemical equivalent of silver. 
We are indebted to the University of Illinois for the use of part of the apparatus and materials for the iodine voltameter. These were loaned through the courtesy of Prof. Washburn, who cooperated with the Director and Dr. Rosa, of the Bureau of Standards, in making this work possible.

WASHINGTON, January 2, I9I4. 


